Seminars, Conferences, Addresses

\title{
Summary of the Proceedings of the Fourth International Economics Seminar
}

\author{
World Bank, Washington, DC \\ 13-14 Dhü al Qa'dah 1412/ 16-17 May 1992
}

The theme of the Fourth International Islamic Economics Seminar was "Economic Growth and Human Resource Development in an Islamic Perspective." It was a joint undertaking of the Association of Muslim Social Scientists (AMSS) and the International Institute of Islamic Thought 
(IIIT). The program was divided into five sessions: a) Human Resource Development in an Islamic Perspective; b) Human Resource Development in a Comparative Perspective; c) Issues in Human Resource Development: Case Studies from Selected Muslim Countries; d) Human Resources, Economic Development, and Government Policies in Muslim Countries; and e) Business Sector and Human Resource Development. This latter session also dealt with the role of financial institutions in human development from an Islamic perspective. Welcoming and opening remarks were made by Sultan Ahmad of the World Bank and Sayyid Syeed of the AMSS.

Osman Suliman's (Grambling State University, Grambling, LA) paper, "Human Resource Development in a Poor-Capital Economy: The Case of an Islamic Country," examined a production function possessing the characteristics of a poorly trained labor force, which was empirically estimated by using data on the Sudanese economy. Masudul A. Choudhury (University College of Cape Breton, NS, Canada) presented his mathematical paper entitled "An Islamic Knowledge Based Worldview in Development Studies." His main theme was that an Islamic approach to development theorizing differs substantially from the pluralistic approaches of mainstream economics.

Syed I. Mahdi (Benedict College, Columbia, SC), in his paper "Economic Growth and Human Resource Development in Neoclassical and Islamic Economics," asserted that unlike Adam Smith's philosophy of capitalism, an individual's existence is not conceivable outside the Islamic community or society. An Islamic economy would not allow an island of prosperity in the midst of a sea of poverty. Solaiman Mandal (Rajshahi University, Rajshahi, Bangladesh) emphasized that Islamic economic development is a long process that involves enhancing the material and spiritual welfare of human being through efficient allocation of productive resources and equitable distribution income from production and exchange of goods and services.

Ataul Haq Pramanik (International Islamic University, Selangor, Malaysia), in his paper "Human Development in the Context of Some Resource-Rich Education-Poor, Education-Rich Resource-Poor Developing Counties," pointed out that no nation regardless of its successes in human development, can be completely successful without ethical, moral, and spiritual considerations. Jamshed Uppal (Catholic University, Washington, DC) discussed "Investment in Human Capital Financed by Profit and Loss Sharing Contracts," analyzed the question of investment levels in human capital in an economy, where financing is based not on interestbearing credit but profit and loss sharing arrangements.

In a related paper, Abdul Aziz (Humboldt State University, Arcata, CA) discussed the principles and techniques of human resource development. The main these of his paper was that the guidelines concerning the 
principles and techniques of human resource development are given by Qur'an and Hadith and Western capitalistic systems have been trying to adopt these guidelines by trial and error.

Other noteworthy papers were given by Arif Ersoy, Amer Araim, A. F. Alhajji, Jamal Abu Rashid, Ghulam Haniff, Ali Darrat, Abdel Hameed Bashir, and J. W. Wright. Most of the papers presented or submitted are currently under professional review for consideration as regards their inclusion in a book of proceedings, scheduled to be published next year.

The papers presented in the Third International Islamic Economics Seminar were revised and published with the help of the Islamic Development Bank. Published as Resource Mobilization and Investment in an Islamic Economic Framework, it was released at the Fourth International Economics Seminar and is available from the AMSS headquarters.

Ehsan Ahmad Associate Professor of Economics James Madison University Harrisonburg, Virginia 